\title{
PERAN KEGIATAN PRAMUKA DALAM PENGEMBANGAN SIKAP NASIONALISME SISWA MAN 1 BANYUWANGI
}

\author{
Nopalta Bagus Samudra, M. Mansur Ibrahim, M. Syahri \\ FKIP Universitas Muhammadiyah Malang \\ nofaltabagus123@gmail.com
}

\begin{abstract}
ABSTRAK
Penelitian ini bertujuan untuk memperoleh data tentang pelaksanaan, kendala, solusi, serta peran kegiatan pramuka dalam pengembangan sikap nasionalisme siswa MAN 1 Banyuwangi, Kecamatan Banyuwangi, Kabupaten Banyuwangi. Penelitian ini menggunakan pendekatan kualitatif dengan data yang dijabarkan berupa data deskriptif. Lokasi penelitian adalah MAN 1 Banyuwangi. Sumber data dalam penelitian ini dibagi menjadi dua yaitu sumber data primer dan sumber data sekunder. Teknik pengumpulan data pada penelitian ini menggunakan wawancara, obervasi dan studi dokumen. Teknik analisis data tersebut berupa reduksi data, penyajian data, dan verifikasi data. Hasil penelitian menunjukkan peran kegiatan pramuka dalam pengembangan sikap nasionalisme siswa MAN 1 Banyuwangi, pada tahap pelaksanaan kegiatan pramuka MAN 1 Banyuwangi menggunakan metode kepramukaan yang berpedoman pada buku satuan kecakapan umum pramuka. Pada penelitian ini terdapat faktor penghambat yaitu kurangnya minat siswa, serta jumlah pembina yang tidak seimbang. Solusi untuk kendala yang dihadapi yaitu dengan pemberian sanksi yang tegas, mengadakan latihan dengan cara berpindah-pindah agar siswa lebih antusias, serta melakukan pelatihan kepada pihak guru dan BK untuk meningkatkan SDM tentang kepramukaan. Kemudian peran kegiatan ini dalam pengembangan sikap nasionalisme siswa di MAN 1 Banyuwangi yaitu tidak hanya sebagai pembentuk moral, penanaman nilai nasionalisme dan juga sebagai motivator yang mengajarkan jiwa nasionalisme, disiplin, jujur dan mengajarkan siswa lebih dekat kepada negaranya, peran kegiatan pramuka juga sebagai kegiatan yang menstimulus dan menjaga agar rasa nasionalisme siswa tetap terjaga.
\end{abstract}

Kata Kunci : Pramuka, Sikap Nasionalisme.

\begin{abstract}
This study aims to obtain data on the implementation, constraints, solutions, and the role of scout activities in the development of student nationalism attitude MAN 1 Banyuwangi, District Banyuwangi, Banyuwangi. This study uses a qualitative approach with data that is described in the form of descriptive data. The location of the research is MAN 1 Banyuwangi. Sources of data in this study is divided into two primary data sources and secondary data sources. This research procedure uses interviews, observations and document studies. Data analysis techniques such as data reduction, data presentation, and data verification. The results showed the role of scout activities in the development of student nationalism attitude MAN 1 Banyuwangi, in the implementation stage of the scout MAN 1 Banyuwangi using scouting method based on the general scout skills unit book. In this study there are inhibiting factors that are the lack of student interest, the amount of coach is not balanced. The solution to the obstacles faced is by giving strict sanctions, conducting the exercises by moving around to make the students more enthusiastic, as well as training the teachers and BK to improve the human resources of scouting. Then the role of this activity in the development of students' nationalism attitude in MAN 1 Banyuwangi is not only as a moral builder, the cultivation of the value of nationalism and also as a motivator who teach the soul of nationalism, discipline, honest
\end{abstract}


and teach students closer to his country, the role of scout activities as well as activities stimulate and maintain the sense of student nationalism is maintained.

Keywords: scouting movement, nationalism

\section{PENDAHULUAN}

Kemampuan dan watak serta peradaban bangsa yang bermartabat merupakan tujuan serta fungsi dari pendidikan nasional yang mana hal ini disebutkan dalam pasal Undang-undang No.20 Tahun 2003 tentang Sistem Pendidikan Nasional. Pendidikan nasional mampu melahirkan generasi yang tidak hanya memiliki kemampuan ataupun potensi saja, tetapi diimbangi dengan watak dan peradaban bangsa yang bermartabat, berakhlak mulia, serta selalu beriman dan betaqwa kepada pencipta-Nya dan bertanggung jawab.

Hal tersebut merupakan acuan bangsa Indonesia yang dijadikan dasar serta tujuan pendidikan nasional. Akan tetapi dapat disaksikan bersama, bahwa sekarang ini pendidikan belum menunjukan hasil sesuai dengan harapan yang berdasar kepada landasan dan tujuan pendidikan itu sendiri. Pembentukan manusia yang cerdas yang disertai keimanan dan ketaqwaan serta memiliki budi pekerti yang luhur belum bisa terwujudkan.

Lingkungan masyarakat sekarang ini sangat meresahkan, karena lunturnya nilainilai yang ada dalam lingkungan akibat gejala dari merosotnya nilai, akhlak dan moral dikalangan masyarakat. Nilai-nilai yang ada di masyarakat seperti nilai kasih sayang, keadilan, kujujuran dan sikap tolong menolong pada masyarakat kini hanya slogan saja. Bukan hanya dalam lingkungan masyarakat saja, krisis akhlak juga terjadi dalam kehidupan elite politik telah dikotori dengan adanya fitnah, saling merendahkan elit politik yang lain, politik adu domba, penyelewengan baik kekuasaan serta jabatan, serta perbuatan maksiat lainnya.

Krisis akhlak dapat juga terjadi dalam kehidupan berbagai lapisan masyarakat pada beberapa sikap sebagian dari mereka merampas hak orang lain dengan sangat mudah, seperti mencuri, mencopet serta menjarah. Peran dunia pendidikan sangat penting dan sentral agar siswa (khususnya generasi muda) akan dibawa serta dibimbing menuju perubahan yang berarti perubahan tersebut merupakan suatu kemajuan sosial serta kemajuan bangsa.

Jika pengaruh tersebut terus menerus dibiarkan, bisa kita bayangkan akan memberikan dampak terhadap rusaknya generasi muda. Seperti kebobrokan moral, timbulnya tindakan yang tidak mencerminkan budaya bangsa, lebih bangga terhadap budaya luar dari pada budaya sendiri. Generasi muda adalah generasi penerus bangsa yang menjadi penentu bagaimana bangsa kedepannya dan menjadi seperti apa bangsa ini ada di tangan generasi muda.

Penurunan sikap nasiolisme pada siswa merupakan suatu realita dan memiliki bukti yaitu pada hari senin pada sekolah melakukan kegiatan upacara bendera dalam rangka memperingati HUT RI dan Hari Pendidikan Nasional banyak siswa mengikuti kegiatan upacara dengan tidak hikmat, siswa sambil bergurau dengan temannya. Kemudian kurangnya pemakaian produk dalam negeri dibandingkan produk luar negeri menandakan bahwa siswa tidak mencintai produk negerinya sendiri.

Berdasarkan uraikan diatas, peneliti dapat menyimpulkan bahwa hal tersebut terjadi karena kurangnya kegiatan yang

Nopalta Bagus Samudra, M. Mansur Ibrahim, M. Syahri, Peran Kegiatan Pramuka dalam Pengembangan Sikap Nasionalisme Siswa MAN 1 Banyuwangi 
bersifat mendidik terhadap generasi muda tentang arti penting sikap nasionalisme, sehingga melalui kegiatan pramuka digantungkan suatu harapan agar siswa memiliki jiwa nasionalisme agar mempunyai perasaan cinta terhadap tanah airnya kemudian generasi muda pastinya akan rela berkorban apapun demi bangsanya sehingga generasi muda juga pastinya akan lebih mencintai produk dalam negeri dibanding produk luar. Oleh karena itu, sikap nasionalisme harus dibudayakan kepada generasi muda khususnya dikalangan SMA agar mereka lebih tahu pentingnya rasa nasionalisme sehingga mereka memiliki jiwa nasionalisme agar bangsa Indonesia tetap aman, nyaman dan damai dari gangguan luar.

Berdasarkan hasil observasi awal yang dilakukan peneliti di MAN 1 Banyuwangi dan peneliti juga melakukan wawancara singkat dengan salah satu guru ekstrakurikuler bagian kepramukaan. Bahwa minat siswa rendah untuk mengikuti kegiatan pramuka dan bisa dikatakan tidak diperdulikan oleh sebagian siswa. Rendahnya minat siswa terhadap kegiatan ini menjadikan kurangnya rasa cinta tanah air atau nasionalisme pada sebagian siswa MAN 1 Banyuwangi. Oleh karena itu, perlu adanya pengkajian terhadap kegiatan pramuka yang dilaksanakan di MAN 1 Banyuwangi untuk mengetahui peran kegiatan tersebut sehingga dapat merubah pola pikir siswa supaya memiliki rasa nasionalisme yang tinggi.

Berdasarkan latar belakang pemikiran di atas peneliti tertarik untuk melakukan penelitian yang membahas tentang pelaksanaan kegiatan pramuka di sekolah terhadap perkembangan sikap nasionalisme siswa dan upaya yang dapat digunakan dalam menghadapi permasalahan permasalahan yang timbul mengenai kurangnya sikap nasionalisme dengan menggunakan kegiatan ekstrakurikuler kepramukaan pada siswa khususnya MAN 1 Banyuwangi.

\section{METODE}

Jenis penelitian yang digunakan adalah penelitian deskriptif kualitatif yang menghasikan data-data deskriptif berupa kata-kata tulisan atau lisan dari orangorang dan perilaku yang dapat diamati. Sehingga data yang dikumpulkan adalah yang berupa kata atau kalimat maupun gambar (bukan angka-angka). Data-data ini bisa berupa naskah wawancara, catatan lapangan, foto, video, dokumen pribadi, memo ataupun dokumen resmi. Subjek penelitian dalam penelitian ini adalah Pembina pramuka, Kepala sekolah, guru, dan siswa yang mengikuti kegiatan pramuka. Lokasi yang dijadikan tempat penelitian adalah Madrasah Aliyah Negeri 1 Banyuwangi. Penelitian ini dilaksanakan pada bulan Agustus s/d Desember 2017. Prosedur penelitian terdiri dari:(1) tahap pra lapangan meliputi: menyusun rancangan penelitian, menentukan lokasi penelitian, mengurus surat perizinan untuk melakukan penelitian, observasi lapangan, menyiapkan alat-alat yang dibutuhkan dalam proses penelitian dan menyiapkan mental serta akhlak yang baik; (2) tahap pekerjaan lapangan meliputi: melakukan penelitian untuk memperoleh informasi tentang pelaksanaan, hambatan, solusi dan peran kegiatan pramuka serta melakukan wawancara dengan subjek penelitian; dan (3) tahap penyusunan laporan meliputi: menyusun bab 4 dan bab 5 berdasarkan data yang diperoleh.

Instrumen penelitian terdiri dari: (1) observasi digunakan untuk mengamati pelaksanaan, hambatan, solusi serta peran kegiatan pramuka di MAN 1 Banyuwangi, 
(2) wawancara digunakan untuk mengetahui lebih jelas bagaimana proses pelaksanaan kegiatan pramuka, penghambat pelaksanaan kegiatan pramuka, solusi untuk mengantisipasi penghambat pelaksanaan kegiatan pramuka, serta untuk mengetahui peran kegiatan pramuka dalam pengembangan sikap nasinonalisme siswa MAN 1 Banyuwangi; (3) dokumentasi digunakan untuk mendekomentasikan kejadian-kejadian dilapangan.

Teknik analisis data terdiri dari: (1) pengumpulan data meliputi: Peneliti melakukan pengumpulan semua data yang berkaitan dengan penenlitiannya secara objektif, apa adanya serta sesuai dengan hasil observasi, wawancara dilakukan terhadap responden terkait serta dokumentasi kegiatan yang berkaitan dengan judul penelitian; (2) reduksi data meliputi: Reduksi data merupakan bentuk analisis data yang menajamkan, menggolongkan, mengarahkan, dan membuang yang tidak perlu dan mengorganisasikan data sekunder sedimikian rupa sehingga dapat ditarik dan diverifikasi. Reduksi data dilakukan pada saat peneliti mengolah dan memilah pada saat menganalisis data. Penelitian merangkum, melihat hal-hal pokok dan memfokuskan pada hal-hal penting yang harus dipaparkan terkait dengan penelitian di MAN 1 Banyuwangi serta membuang data yang tidak perlu untuk proses analisis data; (3) penyajian data meliputi: Penelitian melakukan penyajian data yang akan memudahkan untuk memahami data atau sekumpulan informasi yang telah diperoleh dari berbagai sumber dilapangan dan telah disusun serta sistematis sehingga dapat memberikan kemungkinan adanya penarikan kesimpulan dan pengambilan tindakan selanjutnya berdasarkan data yang diperoleh dari sumber data di MAN 1
Banyuwangi yang dijadikan lokasi penelitian; dan (4) penarikan kesimpulan meliputi: Penarikan kesimpulan dilakukan oleh peneliti secara terus menerus selama berada dilapangan yang kemudian kesimpulan itu digunakan untuk menjawab rumusan masalah yang dilakukan pada saat mengolah dan menganalisis data dari hasil penelitian. Verifikasi data adalah penarikan kesimpulan oleh peneliti berdasarkan analisis data penelitian. Kesimpulan adalah suatu tinjauan ulang pada catatan dilapangan atau kesimpulan dapat ditinjaua sebagai yang timbul dari data yang harus diuji kebenaran, kekokohan, dan kecocokannya yang merupakan validitasnya.

\section{HASIL DAN PEMBAHASAN}

Berdasarkan hasil observasi bahwa pelaksanaan kegiatan pramuka di MAN 1 Banyuwangi disesuaikan dengan motode kepramukaan. Hal ini dapat dilihat dari pelaksanaan kegiatan-kegiatannya seluruh siswa wajib mengikuti kegiatan secara rutin karena merupakan program wajib meskipun mereka mengikuti karena terpaksa. Dalam latihan rutin mingguan ini pembina pramuka sudah menggunakan Metode Kepramukaan. Dalam kegiatan pembelajaran siswa kurang antusias dengan dibentuknya regu kemudian diberi tugas secara mandiri. Selama latihan rutin mingguan yang berlangsung pada bulan 2017 dapat diketahui bahwa pelaksanaan kegiatan Ekstrakurikuler Pramuka di MAN 1 Banyuwangi sudah disesuaikan dengan program yang telah dibuat oleh pihak mandrasah. Tetapi masih ada keterlambatan dalam pelaksanaan tidak sesuai dengan waktu yang telah ditentukan karena siswa banyak yang terlambat mengikuti kegiatan pramuka.

Faktor atau kendala yang dihadapi dalam pelaksanaan kegiatan pramuka yaitu

Nopalta Bagus Samudra, M. Mansur Ibrahim, M. Syahri, Peran Kegiatan Pramuka dalam Pengembangan Sikap Nasionalisme Siswa MAN 1 Banyuwangi 
pembina dan pembantu pembina pramuka MAN 1 Banyuwangi masih kesulitan dalam mengelola siswa atau peserta kegiatan pramuka. Hal ini bisa dilihat siswa asik bermain sendiri hanya sebagian saja yang mendengarkan pembina saat memberikan sebuah materi, bisa dikatakan bahwa siswa mengikuti kegiatan dengan tidak benar terlihat beberapa siswa asik santai sendiri tidak membantu temannya yang melakukan kegiatan bakti sosial. Dengan banyaknya jumlah siswa yang mengikuti yaitu 400 siswa kelas $\mathrm{X}$ dan 400 siswa kelas XI dan terbagi menjadi beberapa regu, pembina hanya 2 dan pembantu pembina hanya 1 , dari masingmasing regu, jarak tiap regu sangat berdekatan, sehingga menimbulkan kegaduhan dan kurangnya ketertiban siswa, siswa tidak berkosentrasi untuk regunya sendiri, kadang bermain dengan regu yang lain dan pelaksanaan kegiatan pun diselang-seling yang mana kelas X dan XI bergantian melaksanakan kegiatan sehingga pertemuan kegiatan kurang maksimal. Hal tersebut dikarenakan kurangnya jumlah pembina pramuka sehingga kesulitan dalam mengondisikan semua siswa. Beberapa hambatan juga ditemukan peneliti selama observasi diantaranya mulai dari kepala madrasah yang melakukan evaluasi dalm kegiatan tersebut, serta pembina beserta pembantunya tidak terlihat melakukan penilaian kepada siswa. Padahal hal tersebut adalah faktor penting agar tujuan kegiatan pramuka dapat tercapai dan juga supaya pihak sekolah dapat mengetahui perkembangan baik dari siswa ataupun kegiatan pramuka itu sendiri.

Solusi untuk untuk mengatasi hambatan yang muncul dalam pelaksanaan kegiatan pramuka ada beberapa hal yaitu dengan memberikan pemahaman lebih mendalam kepada orang tua siswa bahwa kegiatan pramuka dapat memberi dampak yang positif terhadap siswa, menyajikan kegiatan yang lebih menarik sehingga siswa lebih antusias dalam mengikuti kegiatan pramuka, memberikan sanksi yang tegas kepada siswa yang tidak mengikuti kegiatan dan melanggar perintah pembina, mengadakan pelatihan kepada guru-guru sehingga bisa menjadi pembina dan mengadakan pelatihan yang selalu berpindah-pindah agar ada nuansa baru sehingga siswa tidak bosan dalam mengikuti kegiatan pramuka. Pembina pramuka memberikan hukuman kepada siswa yang tidak mengikuti kegiatan dengan baik dengan berupa teguran lisan dan hukuman seperti menulis surah Al-baqarah 100 ayat , kemudian kegiatan dilaksanakan di lokasi yang berpindahpindah agar siswa lebih antusias.

Peran kegiatan pramuka dalam pengembangan sikap nasionalisme siswa yaitu mempunyai peran penting terhadap sikap nasionalisme siswa. Sering ditemui bahwa generasi muda saat ini telah mengalami penurunan nilai-nilai nasionalisme yang berakibat menipisnya rasa cinta tanah air, menurunnya moral dan nilai-nilai Pancasila yang tergerus oleh arus globalisasi. Dengan adanya kegiatan wajib pramuka ini yang dilaksanakan di MAN 1 Banyuwangi akan berdampak pada diri mereka (siswa) yang mana akan membawa siswa menjadi siswa yang mempunyai jati diri, bermoral Pancasila, dan cinta kepada tanah air atau bangsanya yaitu Indonesia. Peran lain dari kegiatan pramuka terhadap sikap nasionalisme siswa melainkan juga sebagai kegiatan yang dapat menstimulus dan menjaga agar rasa nasionalisme siswa tetap terjaga. Hal ini dilakukan agar siswa selaku peserta kegiatan pramuka selalu menjunjung tinggi nilai-nilai yang ada pada Pancasila yaitu nilai religius, gotong-royong, mandiri serta memiliki rasa nasionalisme yang tinggi. 
Hasil wawancara dengan beberapa responden penelitian tentang pelaksanaan kegiatan pramuka di MAN 1 Banyuwangi, maka peneliti dapat menyimpulkan bahwa dalam melaksanakan kegiatan pramuka pihak madrasah telah melakukan persiapan berupa rencana kegiatan tahunan tentang kegiatan pramuka bukan hanya rencana program tahunan saja akan tetapi pihak madrasah juga memiliki rencana anggaran terhadap kegiatan pramuka. Hal tersebut dilakukan agar kegiatan pramuka berjalan dengan lancar dan penyampaian materi dapat dilakukan secara sistematis kareana adanya program yang sudah tersetruktur. pihak sekolah sudah melakukan persiapan baik berupa rencana kegiatan rutin mingguan maupun tahunan sebagai penunjang kegiatan pramuka yang dilaksanakan di MAN 1 Banyuwangi seperti latihan rutin setiap minggunya yaitu pada hari jumat dan hari minggu khusus untuk calon BANSUS, kemah tiga kali dalam setahun, bakti sosial,pelatihan bela negara bersama KODIM dan perkemahan sabtu dan minggu. Kegiatan pramuka di MAN 1 Banyuwangi juga telah disesuaikan dengan buku panduan SKU pramuka.

Hasil wawancara dengan beberapa responden penelitian tentang kendala dalam pelaksanaan kegiatan pramuka di MAN 1 Banyuwangi, maka peneliti dapat menyimpulkan bahwa hambatan dalam pelaksanaan kegiatan pramuka adalah sebagai berikut. (a) siswa kurang disiplin dan kurang serius dalam mengikuti kegiatan, (b) pelaksanaan yang tidak sesuai dari waktu yang telah dijadwalkan, (c) perbandingan jumlah antara pembina dan siswa yang tidak sesuai, (d) antusias dan kedisiplinan siswa dalam mengikuti kegiatan ekstrakurikuler masih kurang.

Hasil wawancara dengan beberapa responden penelitian tentang solusi untuk kendala yang dihadapi dalam kegiatan pramuka, maka peneliti dapat menyimpulkan bahwa solusi untuk kendala yang dihadapai dalam pelaksanaan kegiatan pramuka adalah sebagai berikut. (a) melaksanakan kegiatan dengan cara berpindah-pindah tempat lokasi, (b) menyajikan kegiatan yang lebih menarik, (c) memberikan sanksi yang tegas atas siswa yang kurang disiplin, (d) melakukan peningkatan kualitas SDM pembina maupun guru kelas tentang kepramukaan yang dilaksanakan disekolah misalnya pelatihan bersama kodim, polres dan kwarcab agar jumlah pembina seimbang dengan jumlah siswa yang mengikuti kegiatan pramuka dan pelaksanaan kegiatan menajdi lebih baik lagi dari sebelumnya.

Hasil wawancara dengan beberapa responden penelitian tentang peran kegiatan pramuka dalam pengembangan sikap nasionalisme siswa MAN 1 Banyuwangi sebagai berikut:

Kepala Sekolah MAN 1 Banyuwangi “Drs. H. Soeraji, M.Pdi, M.Ag” mengungkapkan: “Kegiatan pramuka sangat
memiliki peran penting dalam
pengembangan sikap nasionalisme,
karena cikal bakal terbentuknya
sebuah kedisiplinan berawal
dari kegiatan pramuka. Karena
pramuka itu utamanya dan
kuncinya adalah sebuah
kedisiplinan. Kegiatan pramuka
juga sebagai faktor pendukung
terhadap perkembangan sikap
nasionalisme siswa dengan
pembiasaan dengan materi-
materi yang berhubungan
dengan nasionalisme. Dasa
Dharma dan Trisatya seperti

Nopalta Bagus Samudra, M. Mansur Ibrahim, M. Syahri, Peran Kegiatan Pramuka dalam Pengembangan Sikap Nasionalisme Siswa MAN 1 Banyuwangi 
bunyinya berjanji akan mengamalkan Pancasila dan UUD 1945 itu merupakan bagian dari jiwa nasionalisme yang sangat luar biasa. Kegiatan pramuka juga menjadi kegiatan yang memotivasi anak dan membiasakan anak untuk selalu menerapkan jiwa-jiwa patriotisme, jiwa pemuda yang bertanggung jawab, disiplin, jujur, bicara apa adanya, tolong menolong, dan memperhatikan sesama itu merupakan nilai-nilai luhur yang ada di dalam Pancasila" (wawancara pada tanggal 9 Oktober 2017)..

Pembina Kegiatan Pramuka MAN 1 Banyuwangi "Rina Wigati Handayani, S.Pd” mengungkapkan:

"Peranan kegiatan pramuka juga sebagai faktor pendukung pertumbuhan nasionalisme, karena didalamnya terdapat kegiatan-kegiatan yang mana sifatnya menanamkan nilai-nilai nasionalisme seperti latihan upacara, baksos keaman makam pahlawan, dengan adanya kegiatan ini kita dapat menstimulus dan menjaga agar rasa nasionalisme yang di miliki siswa tetap terjaga" (wawancara pada tanggal 6 Oktober 2017).

Berdasarkan hasil penelitian, peneliti dapat menyimpulkan pendapat bahwa: Peran kegiatan pramuka sangat penting sekali tidak hanya sekedar kegiatan saja, melainkan sebagai motivator siswa agar memiliki rasa nasionalisme seperti pahlawan, fasilitator penanamanan moral serta nilai- nilai nasionalisme, pembentukan sikap dan karakter, penegak disiplin, membetuk siswa yang bertanggung jawab, jujur, tolong-menolong, yang mana semua itu terdapat didalam nilai-nilai luhur Pancasila. Kegiatan inipun mendukung siswa dalam pembelajaran di kelas MAN 1 Banyuwangi karena kegiatan ini tidak menganggu, tetapi lebih bermanfaat.

Hasil dokumentasi kegiatan pramuka di MAN 1 Banyuwangi peneliti turun langsung di lapangan agar mendapatkan data seperti foto berikut ini: (1) 4.4 Perkemahan di lapangan MAN 1 Banyuwangi, untuk melatih siswa agar lebih mandiri dan melatih siswa untuk menghadapi keadaan lingkungan sekitar, (2) Gambar 4.5 saat melakukan pelatihan bela negara bersama KODIM Banyuwangi, kegiatan ini dilakukan bertujuan melatih meningkatkan rasa nasionalisme siswa terhadap negara Indonesia. (3) Gambar 4.6 saat melakukan bakti sosial di TMP (Taman Makam Pahlawan) Banyuwangi dalam rangka menghargai jasa pahalawan yang telah gugur.

\section{SIMPULAN}

Berdasarkan hasil temuan dapat ditarik suatu kesimpulan sebagai berikut: (1) Pelaksanaan kegiatan pramuka di MAN 1 Banyuwangi, madrasah berpedoman pada buku Satuan Kecakapan Umum Pramuka dalam penyusunan rencana program atau kegiatan yang menyangkut dengan kepramukaan. MAN 1 Banyuwangi menjadikan kegiatan tahunan maupun mingguan sebagai agenda rutin. Metode kepramukaan telah digunakan oleh pembina dalam kegiatan mengajar kegiatan pramuka. Dengan adanya kegiatan ini madrasah berharap agar bisa membentuk sikap nasionalisme 
pada siswa khususnya siswa MAN 1 Banyuwangi; (2) Hambatan atau Kendala dalam Pelaksanaan Kegiatan Pramuka di MAN 1 Banyuwangi yaitu Pelaksanaan kegiatan di MAN 1 Banyuwangi belum optimal karena tidak sesuainya rencana kegiatan atau program yang disusun oleh pihak madrasah dengan pelaksanaannya, kegiatan pramuka kurang diminati oleh siswa meskipun itu merupakan kegiatan wajib diikuti serta tidak seimbangnya antara jumlah pembina dengan peserta kegiatan pramuka; (3) Solusi yang ditawarkan sekolah di dalam mengatasi hambatan yang muncul pelaksanaan kegiatan pramuka yaitu dengan pemberian sanksi yang tegas dari pihak sekolah bagi siswa yang tidak mentaati praturan selama kegiatan ataupun yang tidak mengikuti kegiatan pramuka secara rutin, mengadakan latihan dengan cara berpindah-pindah tempat agar siswa lebih antusias mengikuti kegiatan pramuka secara rutin, mengevaluasi kegiatan dengan rutin agar mengetahui kekurangan yang terjadi dalam pelaksaan kegiatan pramuka setiap minggunya, melakukan kegiatan dengan tepat waktu agar digunakan secara maksimal, mengubah tata cara pelaksanaan kegiatan agar peserta didik lebih tertarik dan mengikuti kegiatan dengan rajin serta antusias, serta melakukan pelatihanpelatihan kepada pihak guru dan BK untuk meningkatkan SDM tentang kepramukaan, baik sebagai individu maupun sebagai kelompok, dan mengadakan kegiatan pelatihan bersama dengan pihak-pihak terkait baik dari KODIM, Kepolisian, maupun KWARCAB; (4) Peran kegiatan pramuka terhadap sikap nasionalisme siswa sangat banyak sekali peranannya dan semua itu sudah diterapkan. Tidak hanya sebagai pembentuk moral, penanaman nilai nasionalisme dan juga sebagai motivator yang mana di dalam kegiatan selalu mengajarkan jiwa patriotisme, membimbing anak untuk disiplin, mendidik menjadi siswa yang jujur, mengarahkan kepada hal-hal yang positif, memberikan materi tentang perjuangan dan sejarah Indonesia agar menjadikan siswa yang selalu menghargai jasa para pahlawan negara Indonesia, serta membangun karakter siswa yang sesuai dengan nilainilai Pancasila yaitu religius, mandiri, gotong-royong, serta mempunyai rasa nasionalisme yang tinggi dengan memberikan motivasi-motivasi terkait dengan materi, dan pada setiap kegiatan selalu disampaikan untuk mengingatkan peserta kegiatan pramuka agar selalu menanamkan dan mengamalkan nilai-nilai nasionalisme supaya tidak pudar terkikis oleh perkembangan zaman, dan semua merupakan peran kegiatan pramuka untuk melakukan sesuatu perubahan terhadap sikap nasionalisme yang lebih baik lagi. Tidak hanya itu peran kegiatan pramuka terhadap sikap nasionalisme siswa melainkan juga sebagai kegiatan yang dapat menstimulus dan menjaga agar rasa nasionalisme siswa tetap terjaga.

Setelah memperoleh kesimpulan, maka peneliti dapat memberikan saran-saran yang berikan berkaitan dengan kegiatan penelitian guna untuk menghindari kejadiankejadian atau peristiwa-peristiwa yang dibahas dalam skripsi ini, antara lain: (1) Bagi pihak lembaga pelaksanaan kegiatan pramuka di MAN 1 Banyuwangi ada beberapa kendala. Kendala yang paling besar yaitu kurangnya minat dari siswa terhadap kegiatan-kegiatan tersebut sehingga terjadi keterlambatan dalam pelaksanaan kegiatan yang mengakibatkan tidak sesuai dengan rencana yang telah disusun atau ditentukan. Untuk itu perlu dilakukan pembaharuan baik dalam tata cara maupun metode yang digunakan agar

Nopalta Bagus Samudra, M. Mansur Ibrahim, M. Syahri, Peran Kegiatan Pramuka dalam Pengembangan Sikap Nasionalisme Siswa MAN 1 Banyuwangi 
lebih menarik dan tidak membosankan, evaluasi harus dilaksanakan pada setiap kegiatan agar mengetahui kendala-kendala yang dihadapi untuk dianalisis supaya kegiatan lebih baik lagi kedepannya; (2) Bagi peneliti selanjutnya diharapkan untuk lebih banyak mengkaji referensi maupun sumber yang terkait dengan kegiatan pramuka dan nasionalisme agar hasil penelitiannya lebih baik dan lebih lengkap lagi.

\section{DAFTAR PUSTAKA}

Arikunto, S. 2010. Prosedur Penelitian: Suatu Pendekatan Praktik (Edisi Revisi). Jakarta: Rineka Cipta.

Dunia perpustakaan. 2016. Pengertian pramuka dan kepramukaan. (online) http://www.daftarpustaka.web.id/ 2016/02/pengertian-pramukapengertian.html diakses pada 13 Desember 2016 pukul 13.30 WIB

Hamidi. 2010. Metode Penelitian dan Teori Komunikasi. Malang: UMM Press.

Hidayad, Rahmad. 2016. Pengaruh Globalisasi Terhadap Nilai Naionalisme Pancasila. (online) http:/ /www.tappdf.com/read/4421pengaruh-globalisasi-terhadap-nilainasionalisme-researchgatediakses pada tanggal 21 april 2017 pukul 10.48 wib

Huri, Ainul. 2013. Pembudayaan Nasionalisme di SMP Islam AlKarimahtemuroso Guntur Demak (online) http://e-journal.ikipveteran.ac.id/index.php/democratia/article/view/214 diakses pada 6 desember 2016 pukul 13.36 WIB

Ilmu busra. 2011. Visi Misi dan Strategi Gerakan Pramuka. (online). http:// www.ilmubusra.wordpress.com/2011/ 08/22/visi-misi-dan-strategi-gerakan- pramuka.html . diakses pada 15 Desember 2016 pukul 12.39 WIB

Kementerian Pendidikan dan Kebudayaan Tahun 2014. Tentang Kepramukaan (online) www.kemdikbud.go.id di akses pada 13 Desember 2016 pukul 13.49 WIB

Kompas. 2017. Tentang Boedi Utomo Sang Penanda Kebangkitan Nasionalisme (online). http:// nasional.kompas.com/read/2017/05/ 20/06142521/boedi.oetomo.sang enanda.kebangkitan.nasionalisme. diakses pada 22 Mei 2017 pukul 8.05 WIB

Kurnia, Rohmat. Sejarah Gerakan Pramuka. Jakarta: Kwartir Nasional Gerakan Pramuka

Kwartir Cabang Blora gerakan Pramuka. 2016. Tentang Visi dan Misi Gerakan Pramuka (online). http://pramuka blora. com/tentang-pramuka/visi-misipramuka/ diakses pada 4 Mei 2017 pukul 09.14 WIB

Kwartir Daerah Gerakan Pramuka Jawa Barat. 1998. Pramuka Kader Pembangunan Bangsa. Bandung: CV. Ganjar Negara.

Masbuha. 2014. Tentang Identitas Nasional dan Nasionalisimedi Indonesia (online). http://masbuha. blogspot.co.id/ diakses pada 22 Mei 2017 pukul 8.38 WIB

Moleong, Lexy J. 2014. Metode Penelitian Kualitatif Edisi Revisi. Bandung: PT. Remaja Rosdakarya

Pengertian Para Ahli. 2013. Tentang Pengertian Data dan Jenis Data (online). http://www. pengertianahli. com/2013/11/pengertian-data-danjenis-data.html diakses pada 6 Agustus 2017 pukul 23.24 WIB

Pengertian para ahli. 2014. Pengertian Pramuka dan Sejarah Pramuka.

Jurnal Civic Hukum Volume 3, Nomor 2, November 2018, hal. 216-225 
(online). http://www. pengertianahli. com/2014/01/pengertian-pramukadan-sejarah-pramuka.html. di akses pada 15 Desember 2016 pukul 11.54 WIB

Peraturan Pemerintah Mentri Pendidikan dan Kebudayaan no. 67 tahun 2013 Tentang Tujuan Kurikulum 2013. (online). http://www.kemendikbud. go.id. Diakses pada 20 November 2016 pukul 10.25 WIB

Peraturan Menteri Pendidikan dan Kebudayaan Republik Indonesia Nomor 62 Tahun 2014 tentang Kegiatan Ekstrakurikuler pada Pendidikan Dasar. (online). http:// www.kemendikbud.go.id. Diakses pada 20 November 2016 pukul 10.40 WIB

Prayoga, Nismara. 2014. Buku Panduan Pramuka (online). http://www.scribd. com/mobile/document/291620338/ Buku-Panduan-Pramuka-Lengkap diakses pada 25 Oktober 2017 pukul 16.24 WIB

Pusat Bahasa. 2008. Kamus Besar Bahasa Indonesia Edisi Ke-IV. Jakarta: PT. Gramedia Pustaka Utama

Putra, Nusa \& Hendarman. 2012. Metodologi Penelitian Kebijakan. Bandung: PT.Remaja Rosdakarya.

Sari, Dian Apita. 2016. Tentang Sejarah Singkat Peringatan Hari Kebangkitan Nasional(onliine). http://malahayati.ac.id/?p=26368 diakses pada 25 Mei 2017 pukul 17.59

Sugiono. 2014. Metode Penelitian Pendidikan Pendekatan Kuantitatif, Kualitatif dan $R \& D$. Bandung: Alfabeta

Suryohadiprojo, Sayidiman. Mengobarkan Kembali Api Pancasila. Jakarta: PT Kompas Media Nusantara
Undang-Undang No 40 tahun 2009 tentang Kepemudaan. Badan Pengawasan Keuangan dan Pembangunan. (online). www.BPKP.go.id . Diakses pada 15 Desember 2016 pukul 10.00 WIB

Undang-Undang Nomor 12 Tahun 2010 Tentang Gerakan Pramuka.

Undang-Undang RI No. 12 Tahun 2010. Tentang Gerakan Pramuka. Diakses dari http://pramuka.lk.ipb.ac.id/files/ 2012/11/UU-12-tahun-2010GerakanPramuka.pdf. Pada tanggal 2 Juni 2015 jam, 14.35 WIB.

Wikipedia Ensiklopedia Indonesia. 2015. Tentang Ekstrakurikuler (online). https://id.wikipedia.org/wiki/ Ekstrakurikuler diakses pada 13 Desember 2016 pukul 13.15 WIB

Wikipedia Ensiklopedia Indonesia. 2015. Tentang Nasionalisme (online). https:/ /id.wikipedia.org/wiki/Nasionalisme diakses pada 21 Mei 2017 pukul 16.57 WIB

Yatim, Badri. (1999). Soekarno Islam dan Nasionalisme. Ciputat: PT. Logos wacana Ilmu.

Zuriah, Nurul. 2009. Metodologi Penelitian Sosial dan Pendidikan Teori-Aplikasi. Jakarta: Bumi Aksara

Nopalta Bagus Samudra, M. Mansur Ibrahim, M. Syahri, Peran Kegiatan Pramuka dalam Pengembangan Sikap Nasionalisme Siswa MAN 1 Banyuwangi 
